\title{
PEACE EDUCATION, ENVIRONMENTALISM, AND AMERIGO VESPUCCI
}

\author{
FAZILA DERYA AGİş ${ }^{1}$
}

\begin{abstract}
In this paper, first, I intend to analyze the cognitive metaphors associated with Amerigo Vespucci's letters in Italian and the traces of environmental devastation: "Indians Are Gold," "Animals Are Health," "Oceans are Slaves," and "Nature is a Physician" are some of the cognitive metaphors present in Amerigo Vespucci's letters that are present in this book: Vespucci, Amerigo. Cronache Epistolari: Lettere 14761508. Compiled by: Perini, Leandro. 2013. Florence: Firenze University Press. Second, the letters of Amerigo Vespucci will be investigated in accordance with the following: 1) Amerigo Vespucci's traditional nature love: Judeo-Christian views on nature and Saint Thomas; 2) commercial traces of nature devastation in Amerigo Vespucci, such as researches for gold and commercial ways; and 3) scientific aspects of nature in Amerigo Vespucci. In addition to these, third, the metaphors underlying the games played by children through natural objects in Turkey, Israel, Italy, and England will be analyzed and compared, and a peace education theory based on ecocriticism will be proposed.
\end{abstract}

Keywords: Environmental humanities, ecological history, Amerigo Vespucci, peace education, children's games in Turkey, Israel, Italy, and England

Agiş, Fazıla Derya. "Peace Education, Environmentalism, and Amerigo Vespucci". idil 6.38 (2017): 2673-2684.

Agiş, F. D. (2017). Peace Education, Environmentalism, and Amerigo Vespucci. idil, 6 (38), s.2673-2684.

\footnotetext{
${ }^{1} \mathrm{Ph}$.D. student, Ankara University, Institute of Socal Sciences, Western Languages and Literatures, Department of Italian Language and Literature, e-mail. fdagis(at(ankara.edu.tr \& deryaagis(at)gmail.com;

This paper was presented at the TWELFTH ASLE BIENNIAL CONFERENCE: RUST/RESISTANCE: WORKS OF RECOVERY, JUNE 20-24, 2017, WAYNE STATE UNIVERSITY, DETROIT MI, U.S.A. via a conference participation grant offered within the 2224-A program by TÜBİTAK (THE SCIENTIFIC AND TECHNOLOGICAL RESEARCH COUNCIL OF TURKEY) and a small grant by ASLE.
} 


\title{
BARIŞ EĞiTiMi, ÇEVRECiLIK VE AMERIGo VESPUCCI
}

\begin{abstract}
öz
Bu çalışmada, öncelikle, İtalyanca olan Amerigo Vespucci'nin mektuplarındaki bilişsel eğretilemeleri ve çevre tahribatının izlerini incelemeyi amaçlıyorum: "Yerliler Altındır," "Hayvanlar Sağlıktır," "Okyanuslar Kölelerdir" ve "Doğa Bir Doktordur" bu kitapta bulunan Amerigo Vespucci'nin mektuplarındaki eğretilemelerden bazılarıdır: Vespucci, Amerigo. Cronache Epistolari: Lettere 1476-1508. Hazırlayan: Perini, Leandro. 2013. Floransa: Firenze University Press. İkinci olarak, Amerigo Vespucci'nin mektupları aşağıdakilere göre analiz edilecektir: 1) Amerigo Vespucci'nin geleneksel doğa sevgisi: doğa hakkındaki Yahudi-Hristiyan görüşler ve Aziz Thomas; 2) Amerigo Vespucci'de doğa tahribatının ticari izleri, altın ve ticari yol arayışları gibi; ve 3) Amerigo Vespucci'de doğaya bilimsel yönden bakışlar. Bunlara ek olarak, üçüncüsü, Türkiye, İsrail, İtalya ve İngiltere'de doğal nesnelerle oynanan oyunlara göz atılacak ve karşılaştırılacaktır. Sonuçta, çevreci eleştiriye dayalı bir barış kuramı ileri sürülecektir.
\end{abstract}

Anahtar Kelimeler: Çevreci beşerî bilimler, çevreci tarih, Amerigo Vespucci, barış eğitimi, Türkiye, İsrail, İtalya ve İngiltere' de çocuk oyunları 


\section{Introduction}

This paper analyzes Amerigo Vespucci's letters from an environmentalist perspective via the Conceptual Metaphor Theory of George Lakoff and Mark Johnson (1980). These letters can be divided into three groups: 1) Amerigo Vespucci's traditional nature love: Judeo-Christian views on nature and Saint Thomas, 2) commercial traces of nature devastation in Amerigo Vespucci, such as researches for gold and commercial ways, and 3) scientific aspects of nature in Amerigo Vespucci. Moreover, the metaphors underlying the games played by children with natural objects in Turkey, Israel, Italy, and England are analyzed and compared, and a peace education theory based on ecocriticism is proposed.

\section{Theoretical Framework: Cognitive Metaphor Theory and Ecocriticism}

Conceptual Metaphor Theory was coined by George Lakoff and Mark Johnson (1980) in a book written by them: Metaphors We Live By, published in 1980. The book explains that the cultural metaphors formulated in people's minds based on objects that they see around shall be divided into two categories as (1) conceptual metaphors and (2) linguistic metaphors. Conceptual metaphors depict a concept with the structural qualities of another (Lakoff and Johnson, 1980: 14), for example, "ANGER IS HEAT," "ANGER IS FIRE," and "ANGER IS HOT FLUID IN A CONTAINER," since an angry person's face may become red (see Chen, 2010: 73). However linguistic metaphors involve either adjectives or adverbs: thus, they can involve metaphorical directions, or orientations as in saying that a person is down for being sad (see Lakoff and Johnson, 1980: 14), or they define a status with ontologies ("middle class"; "true happiness," et cetera (Lakoff and Johnson, 1980: 26 - 27)). Moreover, metonymy is a concept that represents another with the descriptive common particularity of both concepts (Radden and Kövecses, 1996: 21).

Regarding the link between metaphors and ecocriticism, Heise (2002: 149) proposes that Gary Snyder's poem "Walking the New York Bedrock" (1987) depicts the crowded and "artificial environment of Manhattan" by referring to "natural metaphors that assimilate it to a biological ecosystem," since the poem mentions spider-webs and lichen as certain natural organisms in the subway tunnels alongside gingko trees in parks in Manhattan. Additionally, "far from being synonymous with human "self" or "brain," "mind" is an ecological function, a system of feedback loops that turns elementary information into complex structures"; accordingly, cultures, ideas, thoughts, and environment that one lives in and the ecological conditions that one experiences around can be regarded all as an "information system" in a mind-map 
where webs of environmental, or ecological principles, or rules are linked (Iovino, 2010: 760).

This study aims at analyzing similar conceptual metaphors about nature underlying Amerigo Vespucci's letters to those underlying children's games in Turkey, Israel, Italy, and England for proposing a peace education theory.

\section{Methodology and Research Questions}

I gathered my data from the nine letters of Amerigo Vespucci in the following book:

Vespucci, Amerigo. Cronache Epistolari: Lettere 1476-1508. Compiled by: Perini, Leandro. 2013. Florence: Firenze University Press.

The letters written by Amerigo Vespucci published in the book are the following (I refer to some of them in this study):

1) Amerigo Vespucci's letter to his father Mr. Anastagio Vespucci in Florence from Trebbio del Mugello written on October 19, 1476 (pages: 3-4);

2) Amerigo Vespucci's letter to the commissar of the duke of Mantua in Genova from Seville written on December 30, 1492 (page 87);

3) Amerigo Vespucci's letter to Lorenzo di Pierfrancesco dei Medici from Seville written on July 28, 1500 (pages: 88-101);

4) Amerigo Vespucci's letter to Lorenzo di Piefrancesco dei Medici from Capo Verde on June 4, 1501 (pages: 102-108);

5) Amerigo Vespucci's letter to Lorenzo di Pierfrancesco dei Medici from Lisbon written in 1502 (pages: 109-113);

6) Amerigo Vespucci's letter written probably in 1502 to an anonymous Florentine (pages: 114-119);

7) Amerigo Vespucci's letter to Lorenzo di Pierfrancesco dei Medici from Lisbon in 1502-1503. This letter is recognized as "Mundus Novus" [New World] (pages: 120-135);

8) Amerigo Vespucci's letter to Pier Soderini from Lisbon on September 4, 1504 (pages: 136-165); this letter is about the four voyages of Vespucci: a) in 1497, he visited the islands in South America and the east of Brazil; b) in 1499, he visited Brazil and the cape of Saint Augustine; c) in 1500, he visited Rio de la Plata and Rio de Janeiro, and d) in 1503, he visited the Southeastern coasts of South America ("Amerigo Vespucci and the New World," n.d.). 
9) Amerigo Vespucci's letter to Cardinal Francisco Jiménez de Cisneros from Seville on December 9, 1508 (pages: 166-168).

\section{Findings} study:

The metaphors underlying the following in these letters are analyzed in this

1) Amerigo Vespucci's traditional nature love: Judeo-Christian views on nature and Saint Thomas,

2) commercial traces of nature devastation in Amerigo Vespucci, such as researches for gold and commercial ways, and

3) scientific aspects of nature in Amerigo Vespucci.

\section{1. Amerigo Vespucci's traditional nature love: Judeo-Christian views on nature and Saint Thomas}

As Ellsworth Huntington ([1915] 2001) suggests that different climate conditions influence the cultural formation of different ethnic groups, it was common for the native people, living in the Americas not to have neither laws nor regulations. Thus, the inhabitants of the continent of America were living in a natural manner, as narrated by Amerigo Vespucci in his letter to Lorenzo di Pierfrancesco dei Medici which was written in 1502 from Lisbon:

"They have no cloth, either of wool, flax, or cotton, because they have no need of it; nor have they any private property, everything being in common. They live amongst themselves without a king or ruler, each man being his own master, and having as many wives as they please. The children cohabit with the mothers, the brothers with the sisters, the male cousins with the female, and each one with the first he meets. They have no temples and no laws, nor are they idolaters" (Vespucci, 10081011 (translation by Markham); Vespucci, 110 - 111).

Therefore, successively, metaphorically, "LAWLESSNESS IS NATURE" and metonymically, "RELIGIONS / BELIEFS STAND FOR PROGRESS." Vespucci might have proposed that human beings must have worn clothes for his religious knowledge, since the Old Testament mentions the following: "The Lord God made garments of skin for Adam and his wife and clothed them” (Genesis, III - 21).

Therefore, Vespucci thought that the Indians he had encountered had neither regulations nor legal systems; in addition, they were shameless enough to be naked around others; they had no tendency to collect goods, or material objects; they had no guides like kings; they had many wives against what Vespucci was taught as a Catholic; however, these Indians had no religious beliefs. Thus, as these people had no 
systematic way of life, it was right for Vespucci to invade their lands and acculturate them by converting them into Christianity and teaching them how to trade by offering them gifts. As well, clothing them was a good trading opportunity. Vespucci admired nature for trade and commercial opportunities.

Moreover, as the world is a treasure for humans in accordance with the Old Testament, Amerigo Vespucci wrote the following statements to Lorenzo di Piefrancesco dei Medici from Lisbon in 1502:

\footnotetext{
"We saw crystals, and experienced numerous flavors alongside perfumes of spice-sellers and groceries; but they were not known. People of the country talk about gold, other metals, groceries as well as several miracles, but I am on the side of Saint Thomas. Time will show everything" (Vespucci, 113, translation by me).
}

The Italian idiom "to be on the side of Saint Thomas" "means 'to believe without seeing' (Perini, 2013, 113 in Vespucci, 2013, 113). Christopher Columbus believed in Saint Thomas, as well. On the riverside, he had arrived, he decided to build a tower called Saint Thomas; however, he thought that he was in Japan (Ferraro, 66-67). Vespucci read Saint Thomas's Summa Theologica and defended that day light showed the importance of each creature. Thus, Vespucci would admire nature in contrast to his will to benefit from its products and mines. Accordingly, the conceptual metaphor in the mind of Vespucci during his voyages to the Americas was that: "NATURE IS A DIVINE TREASURE / RICHNESS."

\section{2. Commercial traces of nature devastation in Amerigo Vespucci, such as researches for gold and commercial ways}

Amerigo Vespucci had presented an anthropocentric view, before Descartes and Bacon did. His anthropocentric view of nature was based on the Bible where it was mentioned that Noah took many animal pairs on his boat (see Genesis VII:2-3), people should have worn leather clothes (Genesis III:21), and nature was serving human beings. Consequently, Amerigo Vespucci told Lorenzo di Piefrancesco dei Medici in his letter from Lisbon in 1502 that he considered that the inhabitants of the continent of America were extremely primitive, cruel, and violent, as they were usually fighting:

\footnotetext{
"Moreover, they are warriors, and they behave cruelly towards others in their communities; not only their arms, but also their coups are against the wind, as does Petrarch say: arcs, arrows, spears, and stones; they carry shields to protect themselves, because they walk around as nude as they were, when they were born" (Vespucci, 112, translation by me).
} 
Thus, as conceptual metaphorically, "FIGHTS ARE PRIMITIVENESS" in the mind of Vespucci, he considered ceremonies organized for ill people as primitive, as well; however, he saw that the basic economic needs of human beings that consisted of water and food were delivered to them to understand if ill people were healthy enough to eat and survive, or not, as "NATURE IS LIFE," "WATER IS LIFE," and "FOODS ARE LIFE" conceptually, since nobody would survive without these, and Vespucci was aware of this alongside the Indians:

\begin{abstract}
"One of those nets in which they sleep to two trees. They put their dying relation into it, and dance round him the whole of one day. When night comes on they put water and food enough for four or six days at his head, and then leave him alone, returning to their village. If the sick man can help himself, and eats and lives so as to return to the village, they receive him with ceremony, but few are those who escape" (Vespucci, 530-532; translated by Markham).
\end{abstract}

Additionally, Vespucci discovered that American Indians accepted small objects to talk to them as a way of bargaining; thus, "TRADE IS CONTACT":

"That day we worked so hard with this object by giving them our things, such as bells, looking-glasses, and other trifles, that some of them took courage and came to treat with us" (Vespucci, 467-468; translated by Markham).

However, Vespucci cannot understand why these American Indians do not have any commercial activities, since "TRADE IS LIFE" and "NATURE IS A TREASURE":

"They have no commerce, and neither buy nor sell. In conclusion, they live, and are content with what nature has given them. They have none of the riches which are looked upon as such in our Europe and in other parts, such as gold, pearls, or precious stones: and even if they have them in their country, they do not work to get them. They are liberal in their giving, for it is wonderful if they refuse anything, and also liberal in asking, as soon as they make friends" (Vespucci, 521-525; translated by Markham).

Despite the shock he felt at seeing that American Indians were not obsessed with commerce, although they possessed various natural resources, Vespucci was almost proud of trading slaves against the human nature for exploiting people who were different from the Europeans:

"We made sail for Spain with 222 prisoners, 85 our slaves, and arrived in the port of Cadiz on the 15th of October 1498, where we were well received, and where we sold our slaves" (Vespucci, 665-667; translated by Markham).

Consequently, one can obtain the following metaphors underlying the letters of Amerigo Vespucci that show his commercial way of thinking: "INDIANS ARE 
GOLD," "OCEANS ARE SLAVES," and "NATURE IS A PHYSICIAN," as Indians would refer to natural cures, but Europeans would be involved in slave trade by selling the inhabitants of far places that had coasts by the Atlantic Ocean.

\section{3. Scientific aspects of nature in Amerigo Vespucci}

Letters of Vespucci provide us with scientific information in different fields:

a) Astronomy: stars (see Vespucci, 2013: 109); his cosmological knowledge derived from Ptolemy; metaphorically, "STARS ARE GUIDES":

"Thence we sailed rapidly over the ocean along the coast of Africa and part of Ethiopia to the Ethiopic Promontory, so called by Ptolemy, which is now called Cape Verde, and by the Ethiopians Biseghier, and that country Mandraga, $13^{\circ}$ within the Torrid Zone, on the north side of the equinoctial line" (Vespucci, 961-963; translated by Markham).

b) Biological diversity: animals and plants: Vespucci talked about different animal types important in zoology, by saying the following:

\footnotetext{
"Who could talk about numerous things about forest animals, many couples of lions, non-Spanish type cats, that are antipots, many savage wolves, babuns, and monkeys of varios genres, and many big snakes and other animals that I do not believe to be inserted into the ship of Noah" (Vespucci, 110, translation by me).
}

Moreover, Vespucci appreciated divergent colorful birds (see Vespucci, 110). Therefore, metaphorically, "ANIMALS / PLANTS ARE TREASURES," and as sources for food, "ANIMALS / PLANTS ARE HEALTH": Vespucci liked eatable sea animals, such as schripms, fish, et cetera (see Vespucci, 111), and he appreciated healthy plants just like herbalists:

"The fruits are unlike those in our country; and there are innumerable different kinds of fruits and herbs, of which they make bread and excellent food" (Vespucci, 1030-1031; translation by Markham).

c) Biological Anthropology: In a letter Vespucci wrote to an anonymous Florentine person in 1502, he mentioned that Indians' complexions tended to have a different color from his race (see Vespucci, 116): "COLORS STAND FOR DISCRIMINATION" is an active metonymy in this letter.

Moreover, "NATURE IS A TREASURE" for commercial purposes, "PLANTS AND ANIMALS STAND FOR NATURE," as they are fed by natural resources, make the world beautiful, and serve people as healthy food, and "NATURE 
IS A SHELTER" conceptually in terms of Vespucci's thinking, as it provides people with mines, clothing, food, and drinks. Regarding children's games associated with these conceptual metaphors, in Israel, there is a game called "Find the Afikomen":

\footnotetext{
"During Passover, Jews eat unleavened bread called matzo. At dinner, guests participate in a ceremony called a seder, which uses three pieces of matzo. One sheet of matzo is broken in half and wrapped in a napkin or special dedicated cloth. Called the afikomen, this piece of matzo is hidden somewhere in the home. The children at the seder must find the afikomen; the winner usually receives a nominal prize such as a small amount of money or candy" (LeChat, 1999 - 2017, my emphases).
}

Thus, in this Israeli game, "NATURE IS A TREASURE," with ingredients to make candies, or bread, "FOOD IS NATURE," and "NATURE IS THE MOTHER," since nature provides people with wheat with which they make bread; the children playing the game learn to appreciate nature, as it feeds them like a mother through its products. Moreover, they also learn that commerce is important, as an award is offered to the winner, as indicated by Vespucci who offered very small gifts to Indians in compensation for invaluable goods.

In Italy, "lupo delle ore" (wolf of hours) is a well-known children's game:

\begin{abstract}
"This game requires a minimum of 3 players, although groups of 7 players are ideal. One player is the "lupo" ("wolf"), and stands with his back to the others, who form a line at a designated distance from him. The players call out "Lupo che ore sono?" ("Wolf, what time is it?"), and the wolf answers with a number. The players can then take that many steps toward him, and ask again. If, instead of a number, the wolf responds with "Ho fame!" ("I'm hungry!"), he can turn around and try to tag as many of the children as he can before they make it safely back to the starting line" (Keller, 2017, my emphases; my correction).
\end{abstract}

Italian children learn that wolves are dangerous and alert just like wild animals depicted by Vespucci, but they have needs similar to those of the human beings, such as food. In this Italian game, "NATURE IS A SHELTER \& A MOTHER," since children learn to hide in natural places, for instance, they can hide behind the trees, and they become aware of the fact that wolves need food to survive, and nature has many resources, including plants and animals.

In Turkey, children usually play hide and seek in natural spaces: one child is chosen as the IT, he usually counts upto 10, 20, 0r 100, closing her or his eyes in front of a wall or a tree that s the base. As he is counting, the other children rush to find a place to hide. As the IT finishes counting, he starts to try to find each child to make the first one he finds the IT. If the chidren reaches the wall or the tree that is the base before the IT, the IT continues to be the IT again in the new game. In this game, 
"NATURE IS A SHELTER." Indians would fight against their enemies, and Vespucci would capture slaves; in such circumstances, nature is an excellent shelter for escaping from dangerous people.

Moreover, in England many children play a game called "stuck-in-the mud":

"Two people are 'on' (that is depending on the size of the class - my example is for a class of 15-23 students). They have to chase the people that are not 'on' and tag them.

When they have tagged another student who was not on, that person is 'stuck in the mud'. They stand with legs and arms out and they cannot move. The only way to release them is if another person who is not stuck goes under the student that is stuck to free them. They can go through the person's legs, or under their arms.

This continues for about 5-10 minutes or until everybody is stuck." (Headley, "Teaching Ideas," 1998 - 2015).

In this English game, children learn that "EXCESSIVE RAIN IS DANGER," "HARSH NATURAL CONDITIONS STAND FOR DANGER," and "MUD IS DANGER," whereas "NATURE IS A SHELTER," as they can escape. They can also understand that severe natural conditions may damage places where people live, as in floods. According to Vespucci, stars help people find their way, while travelling, or escaping.

Moreover, these games raise consciousness about several issues related to nature as it provides people with food, good quality food brings health, and plants and animals are eaten for health: "ANIMALS AND PLANTS ARE GOLD," "ANIMALS AND PLANTS ARE HEALTH AND WEALTH," "OCEANS AND LANDS ARE SLAVES FOR HUMANS," "NATURE IS A PHYSICIAN," and "HUMANS ARE FORCES": all of these metaphors are present in Vespucci's letters that defend trade as a God's order for the people who benefit from plants and animals.

\section{Conclusion}

To conclude, one can say that most of the conceptual metaphors in Vespucci's mind, discovering the continent of America in the sixteenth century are also valid for today's children who discover the world around them; as they imitate their relatives, they acquire basic knowledge about commercial and scientific practices. Some of these metaphors are "NATURE IS A TREASURE," "NATURE IS A SHELTER," "NATURE IS A A MOTHER," "ANIMALS AND PLANTS ARE GOLD," "ANIMALS AND PLANTS ARE HEALTH AND WEALTH," "OCEANS AND LANDS ARE SLAVES FOR HUMANS," "NATURE IS A PHYSICIAN," and 
"HUMANS ARE FORCES" either as slaves, or as workers and friends who help others.

However, children learn to love others from different cultures, if they get aware of the common conceptual metaphors related to nature and learned through games in the nature, as "NATURE IS A PEACE-BUILDER" is the dominant conceptual metaphor formed after observing the miracles of nature such as colorful flowers, divergent animals, and healing plants, et cetera, as the world is a shared space for all the human beings. Nonetheless, in such cases, children must have been taught about how to admire nature, by playing in gardens, learning about different plants and animals by building empathy towards them rather than thinking about imaginary trade affairs. Vespucci's travels should be taught to children; however, his admiration of nature should be emphasized rather than his wrongdoings, including capturing slaves, or ignoring the needs of Indians. Wrongdoings should be taught as ways of disturbing other creatures, but usefulness of animals and plants to the human well-being should be emphasized just as resources of joy and happiness without any commercial aims. Children should know that animals and plants (mainly flowers) demonstrate certain emotions that they also experience in some circumstances.

Therefore, history education should involve plays in natural places, such as huge gardens and seasides for showing children what types of wrongdoings and good discoveries history has for all.

\section{REFERENCES}

Amerigo Vespucci and the New World, accessed: 05/03/2017. No Date. Web: http://amerigoves.weebly.com/travel-routes.html: "Travel Routes". Amerigo Vespucci and the New World. N. p., 2017. Web. 7 July 2017.

CHEN, Peilei. "A Cognitive Study of “Anger" Metaphors in English and Chinese Idioms." Asian Social Science. 6.8 (2010), pp. 73 - 76. Print.

FERRARO, Giuseppe. 1875. Relazione delle scoperte fatte da C. Colombo da A. Vespucci e da altri dal 1492 al 1506 tratta da manoscritti della Biblioteca di Ferrara e pubblicata per la prima volta ed annotata dal Prof. Giuseppe Ferraro. Bologna: Gaetano Romagnoli.

HEADLEY, Aaron. 1998 - 2015. "Stuck In The Mud". Teaching Ideas. N. p., 2015. Web. 7 July 2017; http://www.teachingideas.co.uk/warm-up-ideas/stuck-inthe-mud 
HEISE, Ursula. K. "Unnatural Ecologies: The Metaphor of the Environment in Media Theory." Configurations, 10.1(2002), pp. 149-168. Project MUSE, doi:10.1353/con.2003.0006.

Holy Bible, New International Version ${ }^{\circledR}$, NIV® Copyright C 1973, 1978, 1984, 2011 by Biblica, Inc. ( Used by permission. All rights reserved worldwide. "New International Version (NIV) - Version Information Biblegateway.Com". Biblegateway.com. N. p., 2017. Web. 7 July 2017.

HUNTINGTON, Ellsworth. [1915] 2001. Civilisation and Climate. Honolulu: University Press of the Pacific.

IOVINO, Serenella. "Ecocriticism, Ecology of Mind, and Narrative Ethics : a Theoretical Ground for Ecocriticism As Educational Practice." Interdisciplinary Studies in Literature and Environment. 17.4 (2010): 759-762. Print.

KELLER, Mark. "Traditional Games Italian Children Play". Our Pastimes. N. p., 2017. Web. 7 July 2017. http://ourpastimes.com/traditional-games-italianchildren-play-5790117.html, Leaf Group Ltd.

LAKOFF, George, and Mark JOHNSON. 1980. Metaphors we live by. Chicago: University of Chicago Press.

LECHAT, Filonia. 1999 - 2017. "Traditional Jewish Children's Games | Ehow". eHow. N. $\quad$ p., 2017. Web. 7 July 2017: http://www.ehow.com/list_5895679_traditional-jewish-children_s-games.html

MARKHAM, Clements R. Letters of Amerigo Vespucci, and Other Documents Illustrative of His Career. 1894. Internet resource. Kindle edition: 2013.

RADDEN, Günter, and Zoltán KÖVECSES. Towards a Theory of Metonymy. Hamburg: Seminar für Englische Sprache und Kultur, 1996. Print.

St. Thomas Aquinas. 1947. The summa theologica. Translators: Fathers of the English Dominican Province. Benziger Bros.

VESPUCCI, Amerigo. Cronache Epistolari: Lettere 1476-1508. Compiled by: Perini, Leandro. 2013. Florence: Firenze University Press. 